\title{
MOLLUSCS FROM THE UPPER MESOPHOTIC ZONE IN A SGARCELY KNOWN REEF OF THE WESTERN EQUATORIAL ATLANTIC
}

\author{
Moluscos da zona mesofótica superior de um recife \\ pouco conhecido do Atlântico Equatorial Ocidental
}

\author{
Cristiane Xerez Barroso1, João Eduardo Pereira de Freitas², Paula Spotorno², \\ Frederico Tapajós de Souza Tâmega ${ }^{4}$, Wilson Franklin Júnior ${ }^{5}$, Helena Matthews-Cascon ${ }^{6}$ \\ ${ }^{1}$ Laboratório de Invertebrados Marinhos do Ceará, Departamento de Biologia, Centro de Ciências, \\ Universidade Federal do Ceará. E-mail: barrosocx@ufc.br \\ 2 Programa de Pós-Graduação em Ciências Marinhas Tropicais, Instituto de Ciências do Mar (Labomar), \\ Universidade Federal do Ceará, Marine Vertebrate Evolution and Conservation Lab - EvolVe, \\ Departamento de Biologia, Centro de Ciências, Universidade Federal do Ceará. E-mail: freitasjep@gmail.com \\ ${ }^{3}$ Programa de Pós-Graduação em Oceanologia, Instituto de Oceanografia, Universidade Federal \\ do Rio Grande. E-mail: paula.spotorno@gmail.com \\ ${ }^{4}$ Programa de Pós-Graduação em Oceanologia, Instituto de Oceanografia, Universidade Federal do \\ Rio Grande. E-mail: fredtamega@gmail.com \\ ${ }^{5}$ Laboratório de Zoobentos, Instituto de Ciências do Mar (Labomar), Universidade Federal do Ceará. \\ E-mail: wilson@ufc.br \\ ${ }^{6}$ Programa de Pós-Graduação em Ciências Marinhas Tropicais, Instituto de Ciências do Mar (Labomar), \\ Laboratório de Invertebrados Marinhos do Ceará, Departamento de Biologia, Centro de Ciências, \\ Universidade Federal do Ceará. E-mail: helenamc@gmail.com
}

\begin{abstract}
Despite the increasing focus on biodiversity of mesophotic coral ecosystems (MCEs) on a global scale, some biological groups, such as molluscs, are still poorly investigated. The taxonomic diversity of the molluscan fauna of a scarcely known MCE of the Western Equatorial Atlantic, Northeastern Brazil, was surveyed. Samples were collected along the shallower strata of the upper mesophotic zone (between 33-36 m depth). Twenty-one taxa (nine species of gastropods, ten species of bivalves, and two taxa of chitons) were listed, two of which (Novastoa sp. and Thylaeodus sp.) are potential endemic species. A new northern limit of distribution of Persicula moscatellii was established and seven species had new bathymetric records for living specimens (Barbatia domingensis, Barbatia cancellaria, Lamychaena hians, Leiosolenus bisulcatus, Pinctada imbricata, Hipponix incurous, and Persicula moscatellii). Hipponix costellatus are the most representative species with 49 individuals,
\end{abstract}

Recebido em: 05/11/2020

Aprovado em: 13/05/2021

Publicado on-line em: 20/12/2021 
followed by Lima caribaea with six individuals. The present work is the first contribution to the knowledge of the molluscan fauna associated with consolidated substrates from this little-known MCE.

Keywords: mesophotic coral ecosystems, tropical reef, molluscan diversity, Brazilian Province, conventional SCUBA.

\section{RESUMO}

Apesar do crescente foco na biodiversidade de ecossistemas de corais mesofóticos (mesophotic coral ecosystems - MCEs) em escala global, alguns grupos biológicos, como os moluscos, ainda são pouco conhecidos. A diversidade taxonômica da fauna de moluscos de um MCE pouco conhecido do Atlântico Equatorial Ocidental, Nordeste do Brasil, foi investigada. As amostras foram coletadas ao longo dos estratos mais rasos da zona mesofótica superior (entre 33 e $36 \mathrm{~m}$ de profundidade). Vinte e um táxons (nove espécies de gastrópodes, dez espécies de bivalves e duas espécies de quítons) foram encontrados, dois dos quais (Novastoa sp. e Thylaeodus sp.) são potenciais espécies endêmicas. Um novo limite norte de distribuição de Persicula moscatellii foi estabelecido e sete espécies apresentaram novos registros batimétricos para espécimes vivos (Barbatia domingensis, Barbatia cancellaria, Lamychaena hians, Leiosolenus bisulcatus, Pinctada imbricata, Hipponix incurvus e Persicula moscatellii). Hipponix costellatus foi a espécie mais representativa, com 49 indivíduos, seguida por Lima caribaea com seis indivíduos. O presente estudo é a primeira contribuição ao conhecimento da fauna de moluscos desse MCE pouco conhecido.

Palavras-chave: ecossistemas de corais mesofóticos, recife tropical, diversidade de moluscos, Provincia Brasileira, SCUBA convencional.

\section{INTRODUCTION}

Mesophotic coral ecosystems (MCEs) occur in tropical and subtropical regions between depths of 30 and $150 \mathrm{~m}$, and are characterised by the presence of light-dependent corals and other organisms typically associated with reef environments (Hinderstein et al., 2010; Pyle \& Copus, 2019). MCEs are usually divided into zones, with the shallowest one being called the 'upper mesophotic zone', comprising reef environments between 30 and $60 \mathrm{~m}$ depth (Rocha et al., 2018).

In Brazilian waters (South-western Atlantic), MCEs are diversified in structural composition, comprising octocoral or black coral forests, rhodolith beds, sponge bottoms, rocky reefs, and other biogenic reefs (Francini-Filho et al., 2019; Soares; Tavares \& Carneiro, 2019). In this region, these ecosystems are distributed from the Great Amazon Reef System (GARS) $\left(5^{\circ} \mathrm{N}\right)$ to at least $24^{\circ} \mathrm{S}$, including the MCEs in oceanic sites, such as the São Pedro and São Paulo Archipelago, Rocas Atoll, Fernando de Noronha Archipelago, and Vitória-Trindade Chain (Amado-Filho et al., 2016, Francini-Filho et al., 2018, 2019; Pinheiro et al., 2017; Rosa et al., 2016).

Relationships between shallow reef biotas and MCEs have been receiving attention due to their potential use as refuge zones by some species during periods of disturbance (deep reef refugia hypothesis) [(Bongaerts et al., 2010); see new definitions in Bongaerts and 
Smith (2019)]. However, some studies have argued that MCEs are unique ecosystems with characteristic biotas, which are also impacted likewise shallow reefs (e.g., Morais \& Santos, 2018; Rocha et al., 2018; Medeiros et al., 2021). Despite the emerging scenario focusing on biodiversity of MCEs on a global scale, some biological groups, such as molluscs, are still poorly investigated (Pyle \& Copus, 2019). The same knowledge gap is also observed in studies addressing the MCEs of Brazilian waters: although the biodiversity and importance of these ecosystems have been the focus of several recent studies, the surveys focused mainly on rhodolith beds, sponges, scleractinian coral, and fishes (e.g., Amado-Filho et al., 2016; Cordeiro et al., 2015; Feitoza; Rosa \& Rocha, 2005; Francini-Filho et al., 2019; Mantelatto; Cruz \& Creed, 2018; Morais \& Santos, 2018; Moura et al., 2016; Pinheiro et al., 2015; Rocha; Rosa \& Feitoza, 2000; Rocha et al., 2018; Rosa et al., 2016; Soares et al., 2018). One exception is the studies of Leal (1991) and Leal and Bouchet (1991) on molluscs ("prosobranch" gastropods) from the MCEs of Fernando de Noronha, Rocas Atoll, and the Vitória-Trindade chain. Recent publication has specifically investigated the scleractinian coral and fishes in the shallower strata of the upper mesophotic zone on the coast of Ceará State (Northeastern Brazil) (Soares et al., 2018). Freitas and Lotufo (2015) also investigated the reef fish assemblages of some reef environments with depths greater than 30 meters, including the area analyzed in this study (Canal das Arabaianas, described below). Nevertheless, the molluscan fauna associated with these MCEs has never been studied.

The present study aims to qualitatively analyse the molluscan fauna on consolidated substrates from the Canal das Arabaianas, a Mesophotic Coral Ecosystems located on the continental shelf adjacent to the Ceará State, northeastern Brazil. This region harbours some of the least studied reef environments of the South-western Atlantic (Castro \& Pires, 2001; Freitas \& Lotufo, 2015; Pinheiro et al., 2018).

\section{MATERIAL AND METHODS}

The Canal das Arabaianas is a reef environment located on the northeast coast of Brazil (South-western Atlantic Ocean), approximately 28.5 km off Fortaleza (Ceará State's capital) $\left(3^{\circ} 32^{\prime} 45.24^{\prime \prime} \mathrm{S}, 38^{\circ} 16^{\prime} 10.74^{\prime \prime} \mathrm{W}\right)$ (Figure 1). This site is made up of a patch reefs surrounded by sandy area. Traditionally, this is an artisanal fishing site that is eventually also visited by recreational divers. This reef ecosystem is classified as an MCE due to its depth (greater than $30 \mathrm{~m}$ ) (sensu Hinderstein et al., 2010).

The width of the continental shelf in the study area is approximately $50 \mathrm{~km}$, where different subaqueous features are found, for example: (1) rigid substrates in the form of ancient shorelines (beachrocks) and/or biogenic reefs and (2) unconsolidated substrates such as subaqueous dunes (Morais et al., 2020).

Consolidated substrate samples, including two scleractinian coral species [Montastrea cavernosa (Linnaeus, 1767) and Siderastrea stellata (Verril, 1868)], which have already been recorded in another MCE in this region (Soares et al., 2018), and unidentified sponges, were collected during an expedition held on 4 July 2009 by conventional SCUBA diving to access the molluscan fauna, under the permission of an official license (SISBIO permit no. 13983-2). The dives were conducted between 33-36 meters deep. Four researchers collected simultaneously to compensate for the reduced bottom time (15 minutes) provided by conventional SCUBA techniques at the depths required in the present study. Consolidated substrate samples were collected and then stored in labelled plastic bags. The samples 
were fixed in 10\% formaldehyde in the laboratory, and after 48 hours the formaldehyde was replaced by $70 \%$ ethanol. The animals were separated under a stereomicroscope and preserved in $70 \%$ ethanol. Molluscs were identified to the lowest possible taxonomic level using appropriate references (e.g., Boyer, 2004; Mikkelsen \& Bieler, 2003; Rios, 2009; Rosenberg, 2009; Warmke \& Abbott, 1962) and by comparison with the lots deposited at the following malacological collections: Prof. Henry Ramos Matthews - series B, Universidade Federal do Ceará (UFC), CE, Brazil (CMPHRM-B), and Museu Oceanográfico Prof. Eliézer de Carvalho Rios, Universidade Federal do Rio Grande (FURG), RS, Brazil (MORG). All collected material was incorporated in the same Institutions (CMPHRM-B and MORG).

Figure 1 - Geographic location of the studied area, NE Brazil. Black circle highlights the Canal das Arabaianas MCE (33-36 meters deep). Black stars point out the location of natural reef environments with intermediate depths ( 16 to $26 \mathrm{~m}$ ), which are located within the Pedra da Risca do Meio Marine State Park. The bathymetric data used were provided by the Geological Survey of Brazil (CPRM) and National Agency for Petroleum, Natural Gas and Biofuels (ANP)

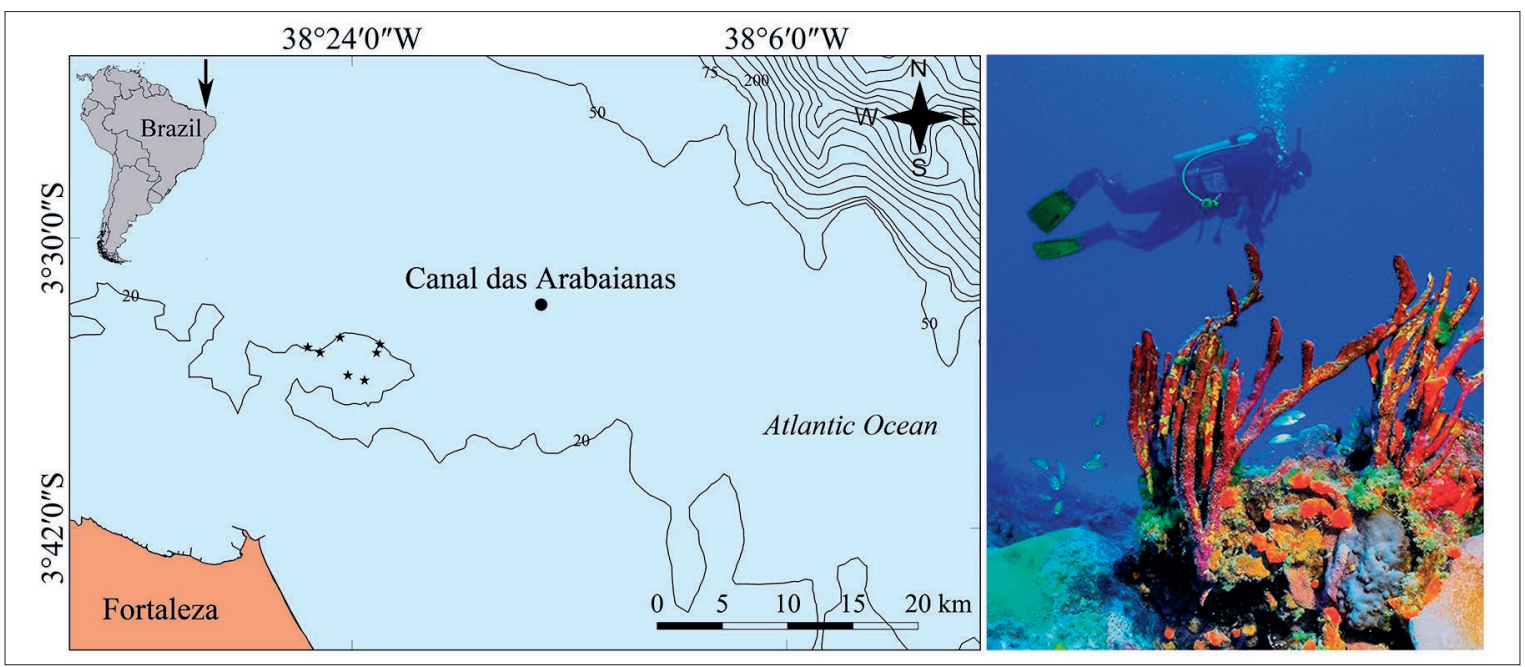

Source: http://www.cprm.gov.br/publique/Geologia/Geologia-Marinha/Projeto-Batimetria- 3224.html). On the right, a photograph of the study area. Photo: Leo Francini.

\section{RESULTS}

We found three classes of Mollusca: Bivalvia, Gastropoda, and Polyplacophora (81 specimens, Table I, Figure 2). Bivalvia was represented by ten species from eight families (Arcidae, Chamidae, Cardiidae, Gastrochaenidae, Limidae, Malleidae, Mytilidae, and Pteriidae). The most representative bivalve species was Lima caribaea d'Orbigny, 1842, with six individuals. Gastropoda, in turn, was represented by nine species from seven families, with Hipponicidae [Hipponix costellatus Carpenter, 1856 and Hipponix incurous (Gmelin, 1791)] being the most representative with 51 individuals. The other families of gastropods were: Cerithiopsidae, Cypraeidae, Marginellidae, Ranellidae, Vermetidae, and Zebinidae. Two specimens of Polyplacophora were identified - Acanthochitona sp. and Acanthochitona cf. terezae Guerra Júnior, 1983) (Table I, Figure 2).

All the molluscs identified to species-level had already been recorded for the coast and/or island environments of Brazil, with the majority having wide geographic distributions (Table I). The present study reported three new records of occurrence for the gastropods Persicula moscatellii Boyer, 2004, whose previous northern limit on the Brazilian coast 
was the Rio Grande do Norte State; and the vermetids Novastoa sp. and Thylaeodus sp., two potential endemic species registered for the first time in the Ceará State. We do not consider the presence of Schwartziella fischeri (Desjardin, 1949) in the Canal das Arabaianas as a new complete occurrence record, because we found only an empty shell. Therefore, we await a future record (including soft parts) to confirm this occurrence. We also do not consider the occurrence of Acanthochitona cf. terezae as a new geographical record, since species identification has not been confirmed.

Our study also reported new bathymetric records for living specimens of Barbatia domingensis (Lamarck, 1819), Barbatia cancellaria (Lamarck, 1819), Lamychaena hians (Gmelin, 1791), Leiosolenus bisulcatus (d'Orbigny, 1853), Pinctada imbricata Roding, 1798, H. incurvus, and Persicula moscatellii (Table I).

Table I - Species of Mollusca collected in the Canal das Arabaianas MCE, Western Equatorial Atlantic

\begin{tabular}{|c|c|c|c|c|}
\hline $\begin{array}{l}\text { Class/ } \\
\text { Family }\end{array}$ & Species & $\begin{array}{l}\text { Number of } \\
\text { individuals }\end{array}$ & $\begin{array}{l}\text { Voucher } \\
\text { number }\end{array}$ & $\begin{array}{l}\text { Geographical }{ }^{\mathrm{a}} \quad \text { and } \\
\text { distribution }\end{array}$ \\
\hline \multicolumn{5}{|l|}{ Bivalvia } \\
\hline \multirow[t]{2}{*}{ Arcidae } & $\begin{array}{l}\text { Barbatia domingensis } \\
\text { (Lamarck, 1819) }\end{array}$ & 2 & CMPHRM6389B & $\begin{array}{l}\text { Bermuda, North Carolina to Texas, } \\
\text { Caribbean Sea, } \\
\text { Venezuela to Brazil (São Pedro and São } \\
\text { Paulo Archipelago). From } 0 \text { to } 140 \mathrm{~m} \text { (live } \\
4 \text { to } \underline{36} \mathrm{~m} \text { ). }\end{array}$ \\
\hline & $\begin{array}{l}\text { Barbatia cancellaria } \\
\text { (Lamarck, 1819) }\end{array}$ & 1 & CMPHRM6391B & $\begin{array}{l}\text { North Carolina to Florida, Texas, Caribbean } \\
\text { Sea, Venezuela, Surinam, and Brazil } \\
\text { (Fernando de Noronha Archipelago, Pará } \\
\text { to Bahia). From } 0 \text { to } 85 \mathrm{~m} \text { (live } 0 \text { to } \underline{36} \mathrm{~m} \text { ). }\end{array}$ \\
\hline Chamidae & Chama sp. & 1 & CMPHRM6383B & - \\
\hline Cardiidae & $\begin{array}{l}\text { Papyridea semisulcata } \\
\text { (J.E. Gray, 1825) }\end{array}$ & $1^{*}$ & CMPHRM6401B & $\begin{array}{l}\text { Bermuda, South Florida, Caribbean } \\
\text { Sea, and Brazil (Fernando de Noronha } \\
\text { Archipelago, Trindade Island, Pará to Rio } \\
\text { de Janeiro). From } 0 \text { to } 100 \mathrm{~m} \text {. }\end{array}$ \\
\hline Gastrochaenidae & $\begin{array}{l}\text { Lamychaena hians } \\
\text { (Gmelin, 1791) }\end{array}$ & 2 & CMPHRM6390B & $\begin{array}{l}\text { Bermuda, North Carolina to Texas, } \\
\text { Caribbean Sea, Venezuela, Surinam to } \\
\text { Brazil (Ceará to Santa Catarina; Abrolhos } \\
\text { Archipelago). From } 0 \text { to } 80 \mathrm{~m} \text { (live } 0 \text { to } \underline{36} \\
\mathrm{~m}) \text {. }\end{array}$ \\
\hline Limidae & $\begin{array}{l}\text { Lima caribaea } \\
\text { (d'Orbigny, 1842) }\end{array}$ & 6 & CMPHRM6386B & $\begin{array}{l}\text { Bermuda, North and South Carolina, } \\
\text { Florida and the Florida Keys, Texas, } \\
\text { the Bahamas, Caribbean Sea, and South } \\
\text { America to Brazil (Fernando de Noronha } \\
\text { Archipelago, Amapá to Rio de Janeiro). } \\
\text { From the shallow subtidal to } 311 \mathrm{~m} \text { (living } \\
\text { specimens). }\end{array}$ \\
\hline \multirow[t]{2}{*}{ Malleidae } & $\begin{array}{l}\text { Malleus candeanus } \\
\text { (d'Orbigny, 1853) }\end{array}$ & 2 & CMPHRM6392B & $\begin{array}{l}\text { Bermuda, South Florida to Texas, } \\
\text { Caribbean Sea, Brazil (Amapá to Bahia, } \\
\text { Abrolhos Archipelago). From } 1 \text { to } 548 \mathrm{~m} \text {. }\end{array}$ \\
\hline & Brachidontes sp. & 3 & CMPHRM6396B & - \\
\hline Mytilidae & $\begin{array}{l}\text { Leiosolenus bisulcatus } \\
\text { (d'Orbigny, 1853) }\end{array}$ & 2 & CMPHRM6385B & $\begin{array}{l}\text { North Carolina to Florida, Texas, } \\
\text { Caribbean Sea, Venezuela, Surinam, and } \\
\text { Brazil (Fernando de Noronha Archipelago, } \\
\text { Trindade Island, Maranhão to São Paulo); } \\
\text { Ascension Island; St. Helena. From } 0 \text { to } 80 \\
\text { m (live } 1 \text { to } \underline{36} \mathrm{~m} \text { ). }\end{array}$ \\
\hline Pteriidae & $\begin{array}{l}\text { Pinctada imbricata } \\
\text { (Roding, 1798) }\end{array}$ & 1 & CMPHRM6400B & $\begin{array}{l}\text { Bermuda, North Carolina to Florida, Texas, } \\
\text { Caribbean Sea, Venezuela, and Brazil (Pará } \\
\text { to Santa Catarina). From } 0 \text { to } \underline{36} \mathrm{~m} \text {. }\end{array}$ \\
\hline \multicolumn{5}{|l|}{ Gastropoda } \\
\hline Cerithiopsidae & $\begin{array}{l}\text { Seila adamsii (H.C. Lea, } \\
\text { 1845) }\end{array}$ & $1^{*}$ & CMPHRM6387B & $\begin{array}{l}\text { North Carolina to Florida, Texas, Caribbean } \\
\text { Sea, Venezuela, Brazil to Uruguay. From } 0 \\
\text { to } 80 \mathrm{~m} \text { (live } 0 \text { to } 20 \mathrm{~m} \text { ). }\end{array}$ \\
\hline
\end{tabular}


(continuation Table l)

\begin{tabular}{|c|c|c|c|c|}
\hline $\begin{array}{l}\text { Class/ } \\
\text { Family }\end{array}$ & Species & $\begin{array}{l}\text { Number of } \\
\text { individuals }\end{array}$ & $\begin{array}{l}\text { Voucher } \\
\text { number }\end{array}$ & $\begin{array}{l}\text { Geographical }{ }^{\mathrm{a}} \text { and } \\
\text { distribution }\end{array}$ \\
\hline Cypraeidae & $\begin{array}{l}\text { Cypraea cf. zebra } \\
\text { (Linnaeus, 1758) }\end{array}$ & 1 & CMPHRM6388B & $\begin{array}{l}\text { N. Carolina to Florida, Texas, W. Indies, } \\
\text { E. Colombia, Venezuela, Surinam, Brazil } \\
\text { (Maranhão to Santa Catarina, Trindade } \\
\text { Island). From } 0 \text { to } 10 \mathrm{~m} \text {. }\end{array}$ \\
\hline \multirow[b]{2}{*}{ Hipponicidae } & $\begin{array}{l}\text { Hipponix costellatus } \\
\text { (Carpenter, 1856) }\end{array}$ & 49 & CMPHRM6384B & $\begin{array}{l}\text { Brazil (Rocas Atoll, Fernando de Noronha } \\
\text { Archipelago, Trindade Island, Ceará to } \\
\text { South Bahia, Abrolhos Archipelago) and } \\
\text { St. Helena. from } 0 \text { to } 60 \mathrm{~m} \text { (live } 0 \text { to } 54 \mathrm{~m} \text { ). }\end{array}$ \\
\hline & $\begin{array}{l}\text { Hipponix incurvus } \\
\text { (Gmelin, 1791) }\end{array}$ & 2 & CMPHRM6395B & $\begin{array}{l}\text { North Carolina to Florida, Caribbean } \\
\text { Sea, East Colombia, Venezuela to Brazil } \\
\text { (Fernando de Noronha Archipelago, } \\
\text { Vitória-Trindade Chain, Amapá to Santa } \\
\text { Catarina, Abrolhos Archipelago). From } 0 \text { to } \\
538 \mathrm{~m} \text { (live } 6 \text { to } \underline{36} \mathrm{~m} \text { ). }\end{array}$ \\
\hline Marginellidae & $\begin{array}{l}\text { Persicula moscatellii } \\
\text { (Boyer, 2004) }\end{array}$ & 1 & CMPHRM6394B & $\begin{array}{l}\text { French Guiana and Brazil (Ceará to Bahia). } \\
\text { From } 20 \text { to } 250 \mathrm{~m} \text { (live } 20 \text { to } \underline{36} \mathrm{~m})\end{array}$ \\
\hline Ranellidae & Cymatium sp. & 1 & CMPHRM6397B & - \\
\hline \multirow{2}{*}{ Vermetidae } & Novastoa sp. & 4 & MORG53731 & - \\
\hline & Thylaeodus sp. & 1 & MORG53732 & - \\
\hline Zebinidae & $\begin{array}{l}\text { Schwartziella fischeri } \\
\text { (Desjardin, 1949) }\end{array}$ & $1^{*}$ & CMPHRM6393B & $\begin{array}{l}\text { Bermuda, Cuba, Caribbean Sea, and } \\
\text { Brazil (Rocas Atoll, Fernando de Noronha } \\
\text { Archipelago, and Abrolhos Archipelago). } \\
\text { From } 0 \text { to } 55 \mathrm{~m} \text { (live } 0 \text { to } 10 \mathrm{~m} \text { ). }\end{array}$ \\
\hline \multicolumn{5}{|l|}{ Polyplacophora } \\
\hline \multirow[t]{2}{*}{ Acanthochitonidae } & Acanthochitona sp. & 1 & CMPHRM6399B & - \\
\hline & $\begin{array}{l}\text { Acanthochitona cf. te- } \\
\text { rezae (Guerra Júnior, } \\
\text { 1983) }\end{array}$ & 1 & CMPHRM6398B & $\begin{array}{l}\text { Brazil (Fernando de Noronha Archipelago, } \\
\text { Ceará** }^{63 \mathrm{~m} .}\end{array}$ \\
\hline
\end{tabular}

Legend: CMPHRM-B - Prof. Henry Ramos Matthews - series B Malacological Collection, Universidade Federal do Ceará, Brazil; MORG - Museu Oceanográfico Prof. Eliézer de Carvalho Rios, Universidade Federal do Rio Grande - FURG, RS, Brazil. * Only shell or valve; ** Record to be confirmed; aReferences: Mikkelsen and Bieler (2003); Boyer (2004); Rios (2009); Jardim, Almeida and Simone (2017), and present study; 'beferences: Mikkelsen and Bieler (2003); Rios (2009); Rosenberg (2009); Jardim, Almeida and Simone (2017), and present study; underlined names and numbers: new geographic or bathymetric record. 
Figure 2 - Species of Mollusca collected in the Canal das Arabaianas MCE, Western Equatorial Atlantic. a. Barbatia domingensis (Lamarck, 1819); b. Barbatia cancellaria (Lamarck, 1819); c. Chama sp.; d. Papyridea semisulcata (J.E. Gray, 1825); e. Lamychaena hians (Gmelin, 1791); f. Lima caribaea (d'Orbigny, 1842); g. Malleus candeanus (d'Orbigny, 1853); h. Brachidontes sp.; i. Leiosolenus bisulcatus (d'Orbigny, 1853); j. Pinctada imbricata (Roding, 1798); k. Seila adamsii (H. C. Lea, 1845); 1. Cypraea cf. zebra; m. Hipponix costellatus (Carpenter, 1856); n. Hipponix incurvus (Gmelin, 1791); o. Persicula moscatellii (Boyer, 2004); p. Cymatium sp.; q. Novastoa sp.; r. Schwartziella fischeri (Desjardin, 1949); s. Thylaeodus sp.; t. Acanthochitona sp.; u. Acanthochitona cf. terezae (Guerra Júnior, 1983). Scale bars $=1 \mathrm{~mm}$

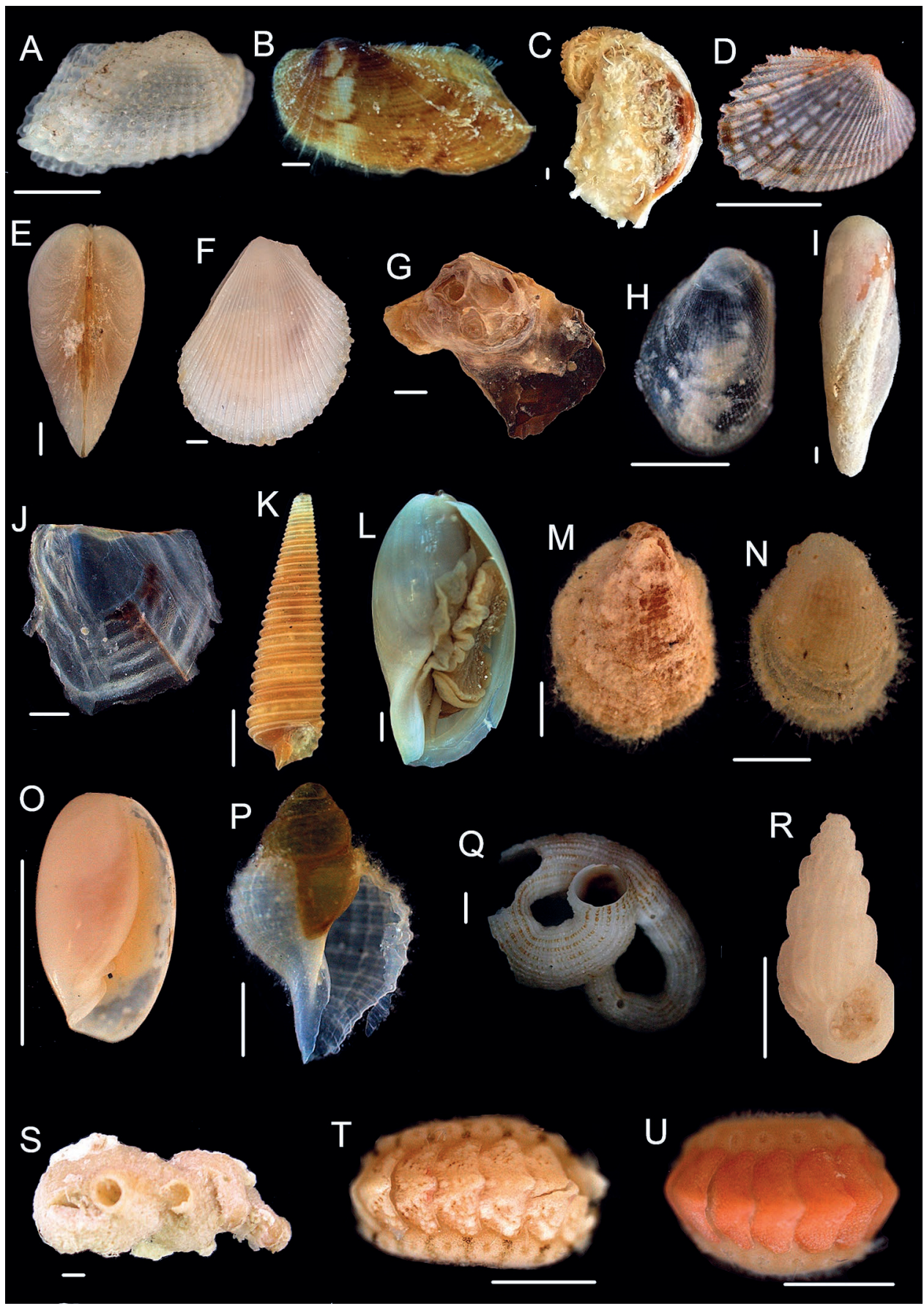




\section{DISCUSSION}

The species found in MCE Canal das Arabaianas are typical of consolidated substrates, such as corals, rocks, and shells, or living in association with marine sponges [e.g., P. imbricata and Malleus candeanus (d'Orbigny, 1853)] and the coralline algae Neogoniolithon sp. [e.g., Novastoa sp. and Thylaeodus sp.] (Culliney, 1971; Mikkelsen \& Bieler, 2003; Moran, 2004; Rios, 2009; Spotorno-Oliveira; Tâmega \& Bemvenuti, 2012).

The vermetids Novastoa sp. and Thylaeodus sp. could be considered potential endemic species from Canal das Arabaianas. Novastoa sp. can readily be distinguished from the same taxon (named as Dendropoma sp.) previous recorded at the oceanic islands (Rocas Atoll and Fernando de Noronha Archipelago) and along the Northeast Brazilian coast (Maranhão, Alagoas, and Bahia) (Spotorno-Oliveira; Tâmega \& Bemvenuti, 2012), by the shell and prehatching larval shells extracted from egg masses. The genus Novastoa Finlay, 1926 was recognised by Golding et al. (2014) after revising the genus Dendropoma Mörch, 1861 (s. lat.) both from a molecular and morphological analyses. Thylaeodus equatorialis Spotorno and Simone, 2013, a species endemic to the São Pedro and São Paulo Archipelago, located at the mid-equatorial Atlantic Ocean (Spotorno \& Simone, 2013), is the unique known Thylaeodus to the Brazilian coast and is easily distinguished by shell sculpture.

In this study, all specimens identified at species level have wide geographical distributions in the Western Atlantic (from the North to South Atlantic), including coastal and insular environments, except for Hipponix costellatus (endemic to Brazilian coast and oceanic islands) and Persicula moscatellii (coast of French Guyana and Brazil), which have a more restricted geographical distribution (Table I). Among these species, besides $H$. costellatus, H. incurvus, B. domingensis, B. cancellaria, L. bisulcatus, Lima caribaea d'Orbigny, 1842, and Papyridea semisulcata (J.E. Gray, 1825) are also distributed on both the Brazilian coast and the oceanic islands (São Pedro and São Paulo Archipelago, Rocas Atoll, Fernando de Noronha Archipelago, and/or Trindade Island) (Table I). The larval development type and/or the presence of a seamounts chain could explain both wide geographical distribution and faunistic similarity between coast and oceanic islands.

Species with planktotrophic development are expected to have higher dispersion potential (broader geographic distribution) than those with non-planktotrophic larvae or a short planktonic period (Jablonski \& Lutz, 1983; Moran, 2004; Thorson, 1950). Barbatia domingensis, B. cancellaria, and L. bisulcatus have planktotrophic larvae (Culliney, 1971; Moran, 2004) and wide geographical distributions (Table I). The larvae of L. bisulcatus can delay metamorphosis that could account for the extensive geographical distribution of this species (Culliney, 1971). Hipponicidae species (e.g., H. costellatus and H. incurvus) contrarily, found in coastal and oceanic Western Atlantic environments, have a short veliger stage (Rios, 2009). The presence of a seamount chain, which can function as stepping stones, linking coastal areas to oceanic islands, can increase the dispersion potential of these species (Barroso et al., 2016; Pinheiro et al., 2017; Simon; Macieira \& Joyeux, 2013). Fernando de Noronha Archipelago and Rocas Atoll are part of an alignment of seamounts of the Brazilian Equatorial Margin, with an east-west orientation, reaching close to the coast of Ceará State (NE Brazil) (Jovane et al., 2016; Morais, 1969; Moura et al., 2019), while Trindade Island is part of the Vitória-Trindade Chain (SE Brazil) (Pinheiro et al., 2017). Unfortunately, there is no specific information about the larval development of L. caribaea (Limidae) and P. semisulcata (Cardiidae), but Limidae species have different development 
strategies (planktotrophic larvae, lecithotrophic larvae, and brooding) (Linse \& Page, 2003) and some species of Cardiidae have planktotrophic larvae (Günther \& Fedyakov, 2000).

In some localities, the shallow and mesophotic reefs are only a few dozen meters apart, providing a higher possibility of vertical connectivity (e.g., Kramer et al., 2019). In other cases, such as in our study region, shallow coastal and upper mesophotic reefs are interspersed by kilometres of unconsolidated substrate (Morais et al., 2020). The presence of coralline algae as substrate for molluscs physically modifies the reef environment and provides hard substrate and microhabitats for larval settlement in a range of marine invertebrates (e.g., Golbuu \& Richmond, 2007; Hayakawa et al., 2008; Spotorno-Oliveira; Figueiredo \& Tâmega, 2015; Swanson et al., 2006). Also, the coralline algae increase the biodiversity in soft-bottom areas and provide refuges for several organisms (Kamenos et al., 2004; Figueiredo et al., 2007; Steller et al., 2003).

Despite this clear spatial separation, our results showed that there might be a connection between the Canal das Arabaianas and shallow coastal reefs located in the intertidal and sublittoral zones since they share common species. More specifically, 33\% of surveyed species [L. caribaea, B. cancellaria, L. hians, L. bisulcatus, P. imbricata, Seila adamsii (H.C. Lea, 1845), and Cypraea cf. zebra (Linnaeus, 1758)] have already been found in the Ceará coast intertidal reefs, according to the records (only specimens with soft parts) of the malacological collection CMPHRM-B. As highlighted in Figure 1, the natural reef environments, located between the coastal reefs and the studied MCE in intermediate depths ( 16 to 26 m) (Freitas \& Lotufo, 2015; Freitas; Araújo \& Lotufo, 2019; Soares et al., 2017), may act as stepping stones and facilitate connection between depth extremes (Bongaerts et al., 2017; Holstein et al., 2016). However, the coexistence of species in adjacent shallow and mesophotic reefs alone is not sufficient to confirm connectivity over ecological time scales. Bongaerts et al. (2017), studying two species of scleractinian corals from shallow and upper mesophotic zones using a next-generation sequencing approach (RAD-seq), found high or very low contemporary connectivity levels, depending on the studied species. It is possible that other biological groups, such as molluscs, may have different levels of vertical connectivity in function of species with distinct life-history traits.

Although some low environmental impact techniques commonly used to study the diversity of MCEs (e.g., visual censuses by divers or analysis of videos captured by remotely operated vehicles - ROVs) are efficient for some biological groups, such as anthozoans and fishes (e.g., Cabaitan et al., 2019; Rocha et al., 2018), they do not appear to be suitable for recording molluscan diversity. Easton et al. (2019), studying the MCEs of Rapa Nui (Easter Island), found that most species found in substrate samples were not observed during ROV imaging surveys. The authors highlighted the need to collect substrate in an initial effort to determine unknown diversity and distribution of molluscan species. The small size of the specimens found in the present study shows that it is challenging to identify species without material collection and subsequent laboratory analysis. Although manual collections, such as the one performed in the present study, have a lower impact when compared to sampling using trawls and dredges, one possible alternative with less impact is the use of recruitment structures that simulate the complexity of reef environments, such as ARMS (Autonomous Reef Monitoring Structures) (Plaisance et al., 2011). This methodology, combined with metabarcoding techniques, has already been shown to be efficient for studying the diversity of cryptic fauna in MCEs (Ransome et al., 2017). 
In conclusion, this study presents, for the first time, data about the malacofauna associated with consolidated substrate in MECs in the Ceará State, reporting new records of occurrence and new bathymetric records for some species. Recently, with the greater access by researchers to advanced diving technologies (e.g., closed-circuit rebreathers), several new species that inhabit MECs are being described, in some cases, at rates higher than those observed in shallow reefs (Pinheiro et al., 2019). In view of the different anthropic impacts that affect MCEs on a global scale (Rocha et al., 2018; Soares et al., 2020a), or even in the study region, where industrial fishing for mesophotic species has occurred since the 1960s (Fonteles-Filho, 2007; Francini-Filho et al., 2019) and an invasive species, the sun coral Tubastraea tagusensis Wells, 1982, has been recorded recently in intermediate $(\sim 22 \mathrm{~m})$ and mesophotic ( $32 \mathrm{~m}$ ) artificial reefs (shipwrecks) (Soares; Davis \& Carneiro, 2018; Soares et al., 2020b), it is possible that part of the diversity of these ecosystems is lost even before it was known. Thus, studies in these areas should be stimulated in order to deepen the knowledge about the biota of the MCEs and consequently base more efficient conservation strategies, for example, including mesophotic reef environments in the design of networks of protected areas.

Acknowledgements - The authors would like to thank Dr. Tito M.C. Lotufo for his support in the fieldwork and laboratory. The authors also wish to thank the photographer Leo Francini for the image of the Canal das Arabaianas used in this study and the Dr. Jaime Jardim for the identification of chitons. The Coordenação de Aperfeiçoamento de Pessoal de Nível Superior (Capes) provided a postdoctoral fellowship to C.X. Barroso (PNPD process number 88882.306440/2018-01), João Eduardo Pereira de Freitas (PNPD, process number 88887.466769/2019-00), P. Spotorno-Oliveira (PNPD, process number 88887.320380/201900), and F.T.S. Tâmega (PNPD, process number 88882.314604/2019-01).

\section{REFERENCES}

Amado-Filho, G.M.; Moura, R.L.; Bastos, A.C.; Francini-Filho, R.B.; Pereira-Filho, G.H.; Bahia, R.G.; Moraes, F.C. \& Motta, F.S. Mesophotic ecosystems of the unique South Atlantic atoll are composed by rhodolith beds and scattered consolidated reefs. Mar. Biodivers., v. 46, n. 4, p. 933-936, 2016. https:/ / doi.org/10.1007/s12526-015-0441-6.

Barroso, C.X.; Lotufo, T.M.C.; Bezerra, L.E.A. \& Matthews-Cascon, H. A biogeographic approach to the insular marine "prosobranch" gastropods from the southwestern Atlantic Ocean. J. Molluscan Stud., v. 82, p. 558-563, 2016. https://doi.org/10.1093/mollus/ eyw015.

Bongaerts, P.; Ridgway, T.; Sampayo, E.M. \& Hoegh-Guldberg, O. Assessing the "deep reef refugia" hypothesis: Focus on Caribbean reefs. Coral Reefs, v. 29, n. 2, p. 1-19, 2010. https://doi.org/10.1007/s00338-009-0581-x.

Bongaerts, P.; Riginos, C.; Brunner, R.; Englebert, N.; Smith, S.R. \& Hoegh-Guldberg, O. Deep reefs are not universal refuges: reseeding potential varies among coral species. Sci. Adv., v. 3, n. 2, p. e1602373, 2017. https:/ / doi.org/10.1126/sciadv.1602373.

Bongaerts, P. \& Smith, B.T. Beyond the "deep reef refuge" hypothesis: a conceptual framework to characterize persistence at depth, p. 881-896, in Loya, Y.; Puglise, K.A. \& Bridge, C.L. (ed.). Mesophotic Coral Ecosystems. Springer, 1005 p., Cham, 2019. https:/ / doi. org/10.1007/978-3-319-92735-0_45. 
Boyer, F. Les groupes Gibberula frumentum (Sowerby, 1832) et G. pulchella (Kiener, 1834) dans l'Atlantique occidental. Novapex, v. 5, p. 33-42, 2004.

Cabaitan, P.C.; Quimpo, T.J.R.; Dumalagan Jr., E.E.; Munar, J.; Calleja, M.A.C.; Olavides, R.D.D.; Go, K.; Albelda, R.; Cabactulan, D.; Tinacba, E.J.C.; Doctor, M.A.A.; Villanoy, C.L. \& Siringan, F.P. The Philippines, p. 265-284, in Loya, Y.; Puglise, K.A. \& Bridge, C.L. (ed.). Mesophotic Coral Ecosystems. Springer, 1005 p., Cham, 2019. https://doi.org/10.1007/ 978-3-319-92735-0_15.

Castro, C.B. \& Pires, D.O. Brazilian coral reefs: what we already know and what is still missing. Bull. Mar. Sci., v. 69, n. 2, p. 357-371, 2001.

Cordeiro, R.T.S.; Neves, B.M.; Rosa-Filho, J.S. \& Pérez, C.D. Mesophotic coral ecosystems occur offshore and north of the Amazon River. Bull. Mar. Sci., v. 91, n. 4, p. 491-510, 2015. http://dx.doi.org/10.5343/bms.2015.1025.

Culliney, J.L. Laboratory rearing of the larvae of the mahogany date mussel Lithophaga bisulcata. Bull. Mar. Sci., v. 21, n. 2, p. 591-602, 1971.

Easton, E.E.; Gorny, M.; Mecho, A.; Sellanes, J.; Gaymer, C.F.; Spalding, H.L. \& Aburto, J. Chile and the Salas y Gómez Ridge, p. 477-490, in Loya, Y.; Puglise, K.A. \& Bridge, C.L. (ed.). Mesophotic Coral Ecosystems. Springer, 1005 p., Cham, 2019. https:/ / doi.org/10.1007/ 978-3-319-92735-0_27.

Feitoza, B.M.; Rosa, R.S. \& Rocha, L.A. Ecology and zoogeography of dee-preef fishes in northeastern Brazil. Bull. Mar. Sci., v. 76, n. 3, p. 725-742, 2005.

Figueiredo, M.A.O.; Menezes, K.S.; Costa-Paiva, E.M.; Paiva, P.C. \& Ventura, C.R.R. Experimental evaluation of rhodoliths as living substrata for infauna at the Abrolhos Bank Brazil. Ciências Mar., v. 33, p. 427-440, 2007. https://doi.org/10.7773/cm.v33i4.1221.

Fonteles-Filho, A.A. Síntese sobre o pargo (Lutjanus purpureus), p. 249-255, in Haimovici, M. (ed.). A prospecção pesqueira e abundância de estoques marinhos no Brasil nas décadas de 1960 a 1990: levantamento de dados e avaliação crítica. Brasília: Ministério do Meio Ambiente, 329 p., 2007.

Francini-Filho, R.B.; Asp, N.E.; Siegle, E.; Hocevar, J.; Lowyck, K.; D’avila, N.; Vasconcelos, A.A.; Baitelo, R.; Rezende, C.E.; Omachi, C.Y.; Thompson, C.C. \& Thompson, F.L. Perspectives on the Great Amazon Reef: Extension, biodiversity, and threats. Front. Mar. Sci., v. 5, n. 142, p. 1-5, 2018. https://doi.org/10.3389/fmars.2018.00142.

Francini-Filho, R.B.; Velásquez, V.M.; Da Silva, M.B.; Rosa, M.R.; Sumida, P.Y.G.; Pinheiro, H.T.; Rocha, L.A.; Ferreira, C.E.L.; Francini, C.L.B. \& De Souza Rosa, R. Brazil, p. 163-198, in Loya, Y.; Puglise, K.A. \& Bridge, C.L. (ed.), Mesophotic Coral Ecosystems. Springer, 1005 p., Cham, 2019. https://doi.org/10.1007/978-3-319-92735-0_10.

Freitas, J.E.P.; Araújo, M.E. \& Lotufo, T.M.C. Composition and structure of the ichthyofauna in a marine protected area in the western equatorial Atlantic: A baseline to support conservation management. Reg. Stud. Mar. Sci., v. 25, p. 100488, 2019. https://doi.org/ 10.1016/j.rsma.2018.100488.

Freitas, J.E.P. \& Lotufo, T.M.C. Reef fish assemblage and zoogeographic affinities of a scarcely known region of the western equatorial Atlantic. J. Mar. Biol. Assoc. United Kingdom, v. 95, n. 3, p. 623-633, 2015. https:// doi.org/10.1017/S0025315414001404. 
Golbuu, Y. \& Richmond, R.H. Substratum preferences in planula larvae of two species of scleractinian corals, Goniastrea retiformis and Stylaraea punctata. Mar. Biol., v. 152, p. 639-644, 2007. https:/ / doi.org/10.1007/ s00227-007-0717-x.

Golding, R.E.; Bieler, R.; Rawlings, T.A. \& Collins, T.M. Deconstructing Dendropoma: a systematic revision of a world-wide worm-snail group, with descriptions of new genera (Caenogastropoda: Vermetidae). Malacologia, v. 57, n. 1, p. 1-97, 2014. https://doi.org/ 10.4002/040.057.0103.

Günther, C.P. \& Fedyakov, V.V. Seasonal changes in the bivalve larval plankton of the White Sea. Senckenbergiana Maritima, v. 30, n. 3-6, p. 141-151, 2000.

Hayakawa, J.; Kawamura, T.; Ohashi, S.; Horii, T. \& Watanabe, Y. Habitat selection of Japanese top shell (Turbo cornutus) on articulated coralline algae; combination of preferences in settlement and post-settlement stage. J. Exp. Mar. Bio. Ecol., v. 363, p. 118-123, 2008. https://doi.org/10.1016/j.jembe.2008.06.033.

Hinderstein, L.M.; Marr, J.C.A.; Martinez, F.A.; Dowgiallo, M.J.; Puglise, K.A.; Pyle, R.L.; Zawada, D.G. \& Appeldoorn, R. Theme section on "Mesophotic Coral Ecosystems: Characterization, Ecology, and Management" Coral Reefs, v. 29, n. 2, p. 247-251, 2010. https://doi.org/10.1007/s00338-010-0614-5.

Holstein, D.M.; Paris, C.B.; Vaz, A.C. \& Smith, T.B. Modeling vertical coral connectivity and mesophotic refugia. Coral Reefs, v. 35, n. 1, p. 23-37, 2016. https://doi.org/10.1007/ s00338-015-1339-2.

Jablonski, D. \& Lutz, R.A. Larval ecology of marine benthic invertebrates: paleobiological implications. Biol. Rev., v. 58, n. 1, p. 21-89, 1983.

Jardim, J.A.; Almeida, S.M. \& Simone, L.L. Redescription of Acanthochitona terezae. J. Conch., v. 42, n. 6, p. 491-497, 2017.

Jovane, L.; Figueiredo, J.J.P.; Alves, D.P.V.; Iacopini, D.; Giorgioni, M.; Vannucchi, P.; Moura, D.S.; Bezerra, F.H.R.; Vital, H.; Rios, I.L.A. \& Molina, E.C. Seismostratigraphy of the Ceará Plateau: Clues to Decipher the Cenozoic Evolution of Brazilian Equatorial Margin. Front. Earth Sci., v. 4, p. 1-14, 2016. doi: 10.3389/feart.2016.00090.

Kamenos, N.A.; Moore, P.G. \& Hall-Spencer, J.M. Maerl grounds provide both refuge and high growth potential for juvenile queen scallops (Aequipecten opercularis L.). J. Exp. Mar. Bio. Ecol., v. 313, p. 241-254, 2004. https://doi.org/10.1016/j.jembe.2004.08.007.

Kramer, N.; Eyal, G.; Tamir, R. \& Loya, Y. Upper mesophotic depths in the coral reefs of Eilat, Red Sea, offer suitable refuge grounds for coral settlement. Sci. Rep., v. 9, n. 1, p. 1-12, 2019. https:/ / doi.org/10.1038/s41598-019-38795-1.

Leal, J.H. Marine prosobranch gastropods from oceanic islands off Brazil, species composition and biogeography. Oegstgeest: Universal Book Services, 419 p., 1991.

Leal, J.H. \& Bouchet, P. Distribution patterns and dispersal of prosobranch gastropods along a seamount chain in the Atlantic Ocean. J. Mar. Biol. Assoc. United Kingdom, v. 71, n. 1, p. 11-25, 1991. https:// doi.org/10.1017/S0025315400037358.

Linse, K. \& Page, T.J. Evidence of brooding in Southern Ocean limid bivalves. J. Molluscan Stud., v. 69, n. 3, p. 290-293, 2003. https:// doi.org/10.1093/mollus/69.3.290. 
Mantelatto, M.C.; Cruz, I.C.S. \& Creed, J.C. A review of the knowledge of shallow subtidal benthic communities in Brazil. Mar. Environ. Res., v. 140, p. 69-77, 2018. https://doi.org/ 10.1016/j.marenvres.2018.05.022.

Medeiros, A.P.M; Ferreira, B.P.; Alvarado, F.; Betancur-R, R.; Soares, M.O. \& Santos, B.A. Deep reefs are not refugium for shallow-water fish communities in the southwestern Atlantic. Ecol. Evol. v. 2021, n. 00, p. 1-15, 2021. https://doi.org/10.1002/ece3.7336.

Mikkelsen, P.M. \& Bieler, R. Systematic revision of the western Atlantic file clams, Lima and Ctenoides (Bivalvia: Limoida: Limidae). Invertebr. Syst., v. 17, n. 5, p. 667-710, 2003. https://doi.org/10.1071/IS03007.

Morais, J.O. Aspectos correlativos de geologia litoral e submarina no Nordeste do Brasil. Arq. Ciên. Mar, v. 9, p. 127-131, 1969.

Morais, J. \& Santos, B.A. Limited potential of deep reefs to serve as refuges for tropical Southwestern Atlantic corals. Ecosphere, v. 9, n. 7, p. e02281, 2018. https://doi.org/10.1002/ ecs2.2281.

Morais, J.O.; Ximenes Neto, A.R.; Pessoa, P.R.S. \& Pinheiro, L.S. Morphological and sedimentary patterns of a semi-arid shelf, Northeast Brazil. Geo-Marine Lett., v. 40, p. 835842, 2020. https:/ / doi.org/10.1007/ s00367-019-00587-x.

Moran, A.L. Egg size evolution in tropical American arcid bivalves: The comparative method and the fossil record. Evolution, v. 58, n. 12, p. 2718-2733, 2004. https://doi. org/10.1554/04-142.

Moura, D.S.; Molina, E.C.; Marangoni, Y.R. \& Jovane, L. Gravity and Magnetic Constraints on the Crustal Structure of the Ceará Plateau, Brazilian Equatorial Margin. Front. Earth Sci., v. 7, p. 1-11, 2019. https://doi.org/10.3389/feart.2019.00309.

Moura, R.L.; Amado-Filho, G.M.; Moraes, F.C.; Brasileiro, P.S.; Saloman, P.S.; Mahiques, M.M.; Bastos, A.C.; Almeida, M.G.; Silva, J.M.; Araujo, B.F.; Brito, F.P.; Rangel, T.P.; Oliveira, B.C.; Bahia, R.G.; Paranhos, R.P.; Dias, R.J.; Siegle, E.; Figueiredo, A.G.; Pereira, R.C.; Leal, C.V.; Hajdu, E.; Asp, NE; Gregoracci, G.B.; Neuman-Leitão, S.; Yager, P.L.; Francini-Filho, R.B.; Fróes, A.; Campeão, M.; Silva, B.S.; Moreira, A.P.; Oliveira, L.; Soares, A.C.; Araújo, L.; Oliveira, N.L.; Teixeira, J.B.; Valle, R.A.; Thompson, C.C.; Rezende, C.E. \& Thompson, F.L. An extensive reef system at the Amazon River mouth. Sci. Adv., v. 2, n. 4, p. 1-12, 2016. https:// doi.org/10.1126/sciadv.1501252.

Pinheiro, H.T.; Mazze, E.; Moura, R.L.; Amado-Filho, G.M.; Carvalho-Filho, A.; Braga, A.C.; Costa, P.A.; Ferreira, B.P.; Ferreira, C.E.; Floeter, S.R.; Francini-Filho, R.B.; Gasparini, J.L.; Macieira, R.M.; Martins, A.C.; Olavo, G.; Pimentel, C.R.; Rocha, L.A.; Sazima, I.; Simon, T.; Texeira, J.B.; Xavier, L.B. \& Joyeux, J.C. Fish biodiversity of the Vitória-Trindade seamount chain, southwestern Atlantic: An updated database. PLoS One, v. 10, n. 3, p. 1-17, 2015. https:/ / doi.org/10.1371/journal.pone.0118180.

Pinheiro, H.T.; Rocha, L.A.; Macieira, R.M.; Carvalho-Filho, A.; Anderson, A.B.; Bender, M.G.; Di Dario, F.; Ferreira, C.E.L.; Figueiredo-Filho, J.; Francini-Filho, R.; Gasparini, J.L.; Joyeux, J.-C.; Luiz, O.J.; Mincarone, M.M.; Moura, R.L.; Nunes, J. de A.C.C.; Quimbayo, J.P.; Rosa, R.S.; Sampaio, C.L.S.; Sazima, I.; Simon, T.; Vila-Nova, D.A. \& Floeter, S.R. South- 
western Atlantic reef fishes: Zoogeographical patterns and ecological drivers reveal a secondary biodiversity centre in the Atlantic Ocean. Divers. Distrib., v. 24, n. 7, p. 951-965, 2018. https:/ / doi.org/10.1111/ddi.12729.

Pinheiro, H.T.; Bernardi, G.; Simon, T.; Joyeux, J.C.; Macieira, R.M.; Gasparini, J.L.; Rocha, C. \& Rocha, L.A. Island biogeography of marine organisms. Nature, v. 549, n. 7670, p. 82-85, 2017. https:/ / doi.org/10.1038/nature23680.

Pinheiro, H.T.; Shepherd, B.; Castillo, C.; Abesamis, R.A.; Copus, J.M.; Pyle, R.L.; Greene, B.D.; Coleman, R.R.; Whitton, R.K.; Thillainath, E.; Bucol, A.A.; Birt, M.; Catania, D.; Bell, M.V. \& Rocha, L.A. Deep reef fishes in the world's epicenter of marine biodiversity. Coral Reefs, v. 38, n. 5, p. 985-995, 2019. https:// doi.org/10.1007/s00338-019-01825-5.

Plaisance, L.; Caley, M.J.; Brainard, R.E. \& Knowlton, N. The diversity of coral reefs: What are we missing? PLoS One, v. 6, n. 10, p. e25026, 2011. https://doi.org/10.1371/journal. pone.0025026.

Pyle, R.L. \& Copus, J.M. Mesophotic Coral Ecosystems: Introduction and Overview, p. 3-27, in Loya, Y.; Puglise, K.A. \& Bridge, C.L. (ed.). Mesophotic Coral Ecosystems. Springer, 1005 p., Cham, 2019. https://doi.org/10.1007/978-3-319-92735-0_1.

Ransome, E.; Geller, J.B.; Timmers, M.; Leray, M.; Mahardini, A.; Sembiring, A.; Collins, A.G. \& Meyer, C.P. The importance of standardization for biodiversity comparisons: A case study using autonomous reef monitoring structures (ARMS) and metabarcoding to measure cryptic diversity on Mo'orea coral reefs, French Polynesia. PLoS One, v. 12, n. 4, p. 1-19, 2017. https:// doi.org/10.1371/journal.pone.0175066.

Rios, E.C. Compendium of Brazilian Sea Shells. Rio Grande: Editora Evangraf, 720 p., 2009.

Rocha, L.A.; Pinheiro, H.T.; Shepherd, B.; Papastamatiou, Y.P.; Luiz, O.J.; Pyle, R.L. \& Bongaerts, P. Mesophotic coral ecosystems are threatened and ecologically distinct from shallow water reefs. Science, v. 361, n. 6399, p. 281-284, 2018. https://doi.org/10.1126/ science.aaq1614.

Rocha, L.A.; Rosa, I.L. \& Feitoza, B.M. Sponge-dwelling fishes of northeastern Brazil. Environ. Biol. Fishes, v. 59, n. 4, p. 453-458, 2000. https://doi.org/10.1023/ A:1026584708092.

Rosa, M.R.; Alves, A.C.; Medeiros, D.V.; Coni, E.O.C.; Ferreira, C.M.; Ferreira, B.P.; De Souza Rosa, R.; Amado-Filho, G.M.; Pereira-Filho, G.H.; De Moura, R.L.; Thompson, F.L.; Sumida, P.Y.G. \& Francini-Filho, R.B. Mesophotic reef fish assemblages of the remote St. Peter and St. Paul's Archipelago, Mid-Atlantic Ridge, Brazil. Coral Reefs, v. 35, n. 1, p. 113 123, 2016. https://doi.org/10.1007/s00338-015-1368-x.

Rosenberg, G. Malacolog 4.1.1: A Database of Western Atlantic Marine Mollusca, 2009. Accessed in: http:/ / www.malacolog.org. Available in: 5 Nov. 2020.

Simon, T.; Macieira, R.M. \& Joyeux, J.C. The shore fishes of the Trindade-Martin Vaz insular complex: an update. J. Fish Biol., v. 82, p. 2113-2127, 2013. https://doi.org/10.1111/ jfb.12126.

Soares, M.O.; Araújo, J.T.; Ferreira, S.M.C.; Santos, B.A.; Boavida, J.R.H.; Costantini, F. \& Rossi, S. Why do mesophotic coral ecosystems have to be protected? Sci. Total Environ., v. 726, p. 138456, 2020a. https:/ / doi.org/10.1016/j.scitotenv.2020.138456. 
Soares, M.O.; Salani, S.; Paiva, S.V. \& Braga, M.D.A. Shipwrecks help invasive coral to expand range in the Atlantic Ocean. Mar. Pollut. Bull., v. 158, p. 111394, 2020b. https://doi. org/10.1016/j.marpolbul.2020.111394.

Soares, M.O.; Rossi, S.; Martins, F.A.S. \& Carneiro, P.B.M. The forgotten reefs: Benthic assemblage coverage on a sandstone reef (Tropical South-western Atlantic). J. Mar. Biol. Assoc. United Kingdom, v. 97, n. 8, p. 1585-1592, 2017. https://doi.org/10.1017/ S0025315416000965.

Soares, M.O.; Davis, M. \& Carneiro, P.B.M. Northward range expansion of the invasive coral (Tubastraea tagusensis) in the southwestern Atlantic. Mar. Biodivers., v. 48, n. 3, p. 16511654, 2018. https://doi.org/10.1007/s12526-016-0623-x.

Soares, M.O.; Davis, M.; Paiva, C.C. \& Carneiro, P.B.M. Mesophotic ecosystems: coral and fish assemblages in a tropical marginal reef (northeastern Brazil). Mar. Biodivers., v. 48, n. 3, p. 1631-1636, 2018b. https://doi.org/10.1007/s12526-016-0615-x.

Soares, M.O.; Tavares, T.C.L. \& Carneiro, P.B.M. Mesophotic ecosystems: Distribution, impacts and conservation in the South Atlantic. Divers. Distrib., v. 25, n. 2, p. 255-268, 2019. https://doi.org/10.1111/ddi.12846.

Spotorno-Oliveira, P.; Figueiredo, M.A.O. \& Tâmega, F.T.S. Coralline algae enhance the settlement of the vermetid gastropod Dendropoma irregulare (d'Orbigny, 1842) in the southwestern Atlantic. J. Exp. Mar. Bio. Ecol., v. 471, p. 137-145, 2015. https://doi. org/10.1016/j.jembe.2015.05.021.

Spotorno-Oliveira, P.; Tâmega, F.T.S. \& Bemvenuti, C.E. An overview of the recent vermetids (Gastropoda: Vermetidae) from Brazil. Strombus, v. 19, p. 1-8, 2012.

Spotorno, P. \& Simone, L.R.L. First record of Thylaeodus (Gastropoda: Vermetidae) from the Equatorial Atlantic Ocean, with the description of a new species. Zoologia, v. 30, p. 88-96, 2013. http:/ / dx.doi.org/10.1590/S1984-46702013000100011.

Steller, D.L.; Riosmena-Rodríguez, R.; Foster, M.S. \& Roberts, C. Rhodolith bed diversity in the Gulf of California: the importance of rhodolith structure and consequences of anthropogenic disturbances. Aquat. Conserv., v.13, p.S5-S20, 2003.https:/ / doi.org/10.1002/ aqc.564.

Swanson, R.L.; Nys, R.; Huggett, M.J.; Green, J.K. \& Steinberg, P. In situ quantification of a natural settlement cue and recruitment of the Australian sea urchin Holopneustes purpurascens. Mar. Ecol. Prog. Ser., v. 314, p. 1-14, 2006. https://doi.org/10.3354/ meps314001.

Thorson, G. Reproductive and larval ecology of marine bottom invertebrates. Biol. Rev., v. 25, p. 1-45, 1950.

Warmke, G.L. \& Abbott, R.T. Caribbean seashells: a guide to the marine mollusks of Puerto Rico and other West Indian islands, Bermuda and the Lower Florida Keys. Wynnewood: Livingston Publishing Company, 352 p., 1962. 